\title{
The Use of Youtube to Increase the Students' Autonomous Learning in the Online Learning Situation
}

\author{
Dedi Supendra $^{1 *}$ and Winanda Amilia ${ }^{2}$ \\ ${ }^{12}$ Department of Curriculum and Educational Technology, Faculty of Education, Universitas Negeri Padang, \\ Indonesia \\ *Corresponding author. Email: dedi.supendra@fip.unp.ac.id
}

\begin{abstract}
The implementation of online learning insisted the students obtain learning materials from various digital media by applying a self-directed learning approach. Youtube as one of the emerging video-based technological applications gives people opportunities to access information from several resources and experts. This article aims to investigate the impact of Youtube as online resources on the students' autonomous online learning and their perceptions of the use of Youtube for online learning. This research applied descriptive quantitative using questionnaires spread to 141 undergraduate students in the Faculty of Education, Universitas Negeri Padang. From the result, it was found that the students perceived more autonomous while searching supporting material on Youtube, from the initiative, responsibility, self-confidence, decision-making aspects. However, the need for good quality of internet connection and credit have been critical issues while engaging with Youtube. In addition, for some materials, it is irrelevant to use material from Youtube for their specific courses.
\end{abstract}

Keywords: Youtube, online resources, online learning, autonomous learning

\section{INTRODUCTION}

The trends on how learning implemented has changed from time to time, such as from conventional pattern to digital, face-to-face to blended learning, and from "chalk and blackboard" to e-learning platforms. This alter happened to be associated with the current development and community needs. The emergence of coronavirus pandemic in early 2020 has not only given negative impact to social and economic, but also educational situation. People are encouraged to stay at home, do physical distancing, and are not allowed to have gathering in large numbers of participants. At last, the Minister of Education and Culture, the Republic of Indonesia, through Circular Letter No. 15 year 2020 about guidelines for organising learning from home in emergency period of coronavirus disease (Covid-19) stated to command the schools to apply online distance learning with the aims at: 1 . ensuring the fulfillment of the rights of students to get educational services during the COVID-19 emergency; 2. protecting education unit residents from the adverse effects of COVID-19; 3. preventing the spread and transmission of COVID-19 in educational units; and 4. ensuring the fulfillment of psychosocial support for educators, students andparents / guardians.
Universitas Negeri Padang as one of the state universities in Indonesia has complied with the government policy. In this condition, the lecturers and the students were encouraged to carry out learning activities online at home. Furthermore, the distance learning platform, www.elearning2.unp.ac.id, which is commonly applied to blended learning situation, then are optimized to fully online learning. This online learning system has emerged the new challenges both for students and lecturers. The Covid-19 Pandemic which suddenly come, making the university learning system were not ready to adapt. The teachers did not prepare the learning materials digitally, and not yet maximized the function of provided online learning platform. The students, at the same time, were not ready to learn online and got difficulty to understand the course materials.

To support the online learning approach, various digital media, applications, platforms, and websites are utilized. One of the well-known platforms which are frequent to apply to optimize the understanding of learning material is Youtube. Youtube is a website that allows someone to produce, share and obtain information in the form of videos, such as music videos, films, video blogs, and even videos that are personally created. According to the CEO of Youtube, Susan 
Wojcicki in 2015, Youtube was first created for a simple reason, namely so that people could broadcast themselves through videos.However, eleven years since its first appearance, Youtube is now the most popular video-based website, and is number two as the largest search engine, and number three most visited after Google and Facebook, and is the third largest social media after Facebook.and WeChat with a number of users of more than one billion users worldwide (SocialCliff, 2016; Smith, 2016).

In October 2015, 82\% of Internet users worldwide access and use Youtube regularly. This proves that Youtube is a media or information source that is in great demand by the world's population.In addition, this data opens opportunities to make Youtube an alternative source of video-based learning that provides a variety of knowledge that can be accessed freely by everyone.Marshal (2015) emphasizes that someone can learn anything from Youtube if he knows how to maximize the potential of Youtube.

Several studies have shown that Youtube has a sizable role in the learning process of a person today.Ena (2015) found that $88.9 \%$ of students stated that learning via Youtube made it easier for them to understand the material.Ena (2015) explains that videos on Youtube can be categorized into two forms, namely: videos that are intentionally made to teach certain materials and videos that support certain learning materials. This shows that Youtube has a role in improving the quality of student learning.

However, in fact, the potential of YouTube is not always maximized as an online learning resource.The number of channels or programs that students can choose from has a bad impact on the use of YouTube as an online learning resource.For this reason, a study is needed to determine the tendency of students to use Youtube to increase their autonomy in online learning.Another opinion was expressed by Hidayati and Listyani (2010), the characteristics of autonomy learning are: 1) independence of others, 2) having selfconfidence, 3 ) behaving in discipline, 4) having a sense of responsibility, 5) behavingbased on own initiative, 6) exercise self-control. Besides, Negoro (2008: 17) stated that there have five characteristics of autonomy learning, such as: owning the freedom to initiate, owning self-confident, be able to take decisions, be able to take responsibility, and be able to adapt with the situation and environment. Therefore, this research would question the utilization of Youtube in online learning to increase the learning autonomy of students.

\section{METHODS}

A descriptive quantitative method was applied to this research using online questionnaires through Google Form to collect the data about the learning autonomy of students with Likert Scale and short response-questions. The respondents were 141 random students of Faculty of Education Universitas Negeri Padang who have experienced the online learning at the second half of semester (March - June 2020). At the beginning of the questionnaires, all respondents should state their willingness and confidentiality to participate in this research. At last, the data was analysed with simple descriptive statistical analysis.

\section{RESULTS AND DISCUSSION}

From the questionnaires given to the respondents, it found that the data about the students' attitude of learning autonomy and their response to supporting and obstacle factors which influence their activities in online learning independently. As the data collected, here is the questionnaire result of five characteristics of learning autonomy using the concept of Negoro (2008), as follows:

Table 1. The data of five characteristics of learning autonomy

\begin{tabular}{|c|c|c|c|c|c|}
\hline \multirow{2}{*}{ No } & \multirow{2}{*}{ Characteristics } & \multicolumn{4}{|c|}{ Scale (\%) } \\
\hline & & $\mathrm{Nev}$ & Sel & Usu & Alw \\
\hline 1 & $\begin{array}{l}\text { Initiative } \\
\text { I have initiative to } \\
\text { search learning video on } \\
\text { Youtube to help me } \\
\text { understand the materials }\end{array}$ & 4 & 35 & 24 & 37 \\
\hline 2 & $\begin{array}{l}\text { Self-confidence } \\
\text { I can understand the } \\
\text { course materials after } \\
\text { watching the learning } \\
\text { videos on Youtube }\end{array}$ & 6 & 30 & 45 & 19 \\
\hline 3 & $\begin{array}{l}\text { Take decision } \\
\text { I can decide which } \\
\text { suitable videos in } \\
\text { Youtube that relevant to } \\
\text { the learning needs }\end{array}$ & 4 & 26 & 51 & 19 \\
\hline 4 & $\begin{array}{l}\text { Responsible } \\
\text { I can control the time } \\
\text { duration I should access } \\
\text { Youtube to my learning } \\
\text { needs and entertainment }\end{array}$ & 2 & 37 & 43 & 18 \\
\hline 5 & $\begin{array}{l}\text { Adaptation } \\
\text { I am getting confused } \\
\text { when I have to learn the } \\
\text { materials from videos } \\
\text { on Youtube }\end{array}$ & 29 & 53 & 13 & 5 \\
\hline
\end{tabular}

From the tabel 1, generally most of participants usually to have learning autonomy while watching learning videos on Youtube. The percentage of five characteristics showed that the students have positive 
attitude on independent learning to use videos from Youtube. For example, the initiative character, 37\% of respondents claimed that they always use Youtube as one of alternative learning resources to understand the course materials with or without the command from the lecturers. Meanwhile, the characteristics of selfconfidence, take decision, and adaptation also describe the incredibly good percentage where almost half of the participants stated that they have these characteristics while learning from Youtube videos, 45\%, 51\%, and $43 \%$ written chronologically. Even though the responsible attitude was questioned in a negative statement, the respondents displayed the positive result where only $5 \%$ of all participants who are confused on understanding the course materials from Youtube video, while $53 \%$ was quite seldom, and $29 \%$ of them had never confused of studying from videos.

However, learning from online materials such as Youtube, somehow, has some barriers which discouraged the students' motivation to learn independently. Based on the short-answer question proposed in the online questionnaires, here are some of the obstacle factors of using video from Youtube as online autonomous learning resource:

Table 2. The obstacle factor of having learning autonomy from Youtube videos

\begin{tabular}{|c|l|c|}
\hline No & \multicolumn{1}{|c|}{ Obstacle factors } & Percentage \\
\hline 1 & $\begin{array}{l}\text { Good quality of internet } \\
\text { connection }\end{array}$ & 44 \\
\hline 2 & $\begin{array}{l}\text { Credit (Internet data } \\
\text { package) }\end{array}$ & 41 \\
\hline 3 & Have no specific materials & 7 \\
\hline 4 & $\begin{array}{l}\text { Guidance needs from the } \\
\text { lecturers }\end{array}$ & 3 \\
\hline 5 & Others & 5 \\
\hline
\end{tabular}

From the tabel 2, two primary causes that the participants were reluctant to study from Youtube videos autonomously are the internet connection quality and the data credit for accessing learning videos on Youtube. Almost half of the research participants (44\%) stated that the quality of internet network affected to the activities of studying from Youtube videos. In addition, the lack of the data credits(41\%) also gave negative impact to their online learning activities from Youtube. Furthermore, few percentages of the respondents said that they need the guidance from the lecturers to choose which the best learning videos they should watch on Youtube since, also related to another factor, some of Youtube videos are irrelevant and untrustworthy.

Utilising Youtube as online learning resource is one of the learning strategies since the advent of digital technologies and, especially in this current pandemic outbreak where the classes were closed, and the students should study at home. In this situation, the knowledge was only transferred from virtual meeting, learning platform, and self-learning from electronic resources. These can trigger the emergence of autonomous learning attitude from the students where the students are expected to learn from various learning media independently. Regarding the potential of Youtube video for students' learning context, Snelson (2011) mentioned that one of the advantages of Youtube is providing virtual video with various topics which can be accessed freely. In addition, Buzzeto-More (2014) expressed that Youtube can increase the interest of students, have the deeper understanding towards the course materials, and also increase the satisfaction level of students to materials in higher education. In the meantime, encouraging learning autonomy in accessing and studying materials from Youtube video can be counterproductive when the students some barriers to face, for example internet network quality and the lack of data credit. Apuke and Iyendo (2018) stated these two factors were the major challenges for students.

\section{CONCLUSION}

Youtube has been one of the well-known learning media for students to study about various certain academic topics. The outbreak of Covid-19 changed how course material delivered and the students are encouraged to be more active to increase their knowledge and understanding using learning platform and application. By doing that, it also increases the learning autonomy of the students in accessing more online resources, especially studying from Youtube video. However, some challenging factors, such as poor quality of internet network and data credit should be confronted by the students which cause the decrease of the students' motivation to learn from Youtube videos.

\section{ACKNOWLEDGMENTS}

The research has been supported by the non-tax state revenue grants from Institute of Research and Community Service, Universitas Negeri Padang. We would like to send our gratitude to all the supporting people for giving constructive suggestion to make this article is possible to publish.

\section{REFERENCES}

[1] Smith, C. (2016). By The Numbers: 125+ Amazing YouTube Statistics. [online] DMR. Available at: http://expandedramblings.com/index.php/youtubestatistics/ [Diakses 28 August 2020].

[2] Snelson, C. (2011). YouTube across the Disciplines: A Review of the Literature. Journal of Online Learning and Teaching, [online] 7(1). 
Available at: http://jolt.merlot.org/vol7no1/snelson_0311.html

[3] Buzzetto-More, N. A. (2014). An examination of undergraduate student's perceptions and predilections of the use of YouTube in the teaching and learning process. Interdisciplinary Journal of E-Learning and Learning Objects, 10, 17-32. Retrieved from http://www.ijello.org/Volume10/IJELLOv10p017032Buzzetto0437.pdf

[4] Apuke, O. D., \&Iyendo, T. O. (2018). University students' usage of the internet resources for research and learning: forms of access and perceptions of utility. Heliyon, 4(12), e01052.

[5] Hidayati, K., \&Listyani, E. (2010). Pengembangan instrument kemandirian belajar mahasiswa. Jurnal Penelitian dan Evaluasi Pendidikan, 14(1).

[6] Negoro, S. (2008). Kecenderungan hidup mandiri. Bandung: Tarsito. 